OPEN ACCESS

Edited by:

Tien Ming Lee,

Sun Yat-sen University, China

Reviewed by:

David Agnew,

Commission for the Conservation of Antarctic Marine Living Resources

(CCAMLR), Australia

Andrew M. Song,

University of Technology Sydney,

Australia

*Correspondence:

Catherine S. Longo

katie.longo@msc.org

tThese authors share senior authorship

Specialty section: This article was submitted to Conservation and Restoration Ecology,

a section of the journal

Frontiers in Ecology and Evolution

Received: 03 December 2020

Accepted: 09 July 2021

Published: 09 August 2021

Citation:

Longo CS, Buckley L, Good SD, Gorham TM, Koerner L, Lees S, Liow SY, Oloruntuyi O, Schley D, Rice $J$ and Currey RJC (2021) A

Perspective on the Role of Eco-Certification in Eliminating Illegal, Unreported and Unregulated Fishing. Front. Ecol. Evol. 9:637228. doi: 10.3389/fevo.2021.637228

\section{A Perspective on the Role of Eco-Certification in Eliminating Illegal, Unreported and Unregulated Fishing}

\author{
Catherine S. Longo ${ }^{*}$, Leah Buckley ${ }^{1}$, Stephanie D. Good², Taylor M. Gorham ${ }^{3}$, \\ Lauren Koerner', Samantha Lees', Shen Yan Liow', Oluyemisi Oloruntuyi', \\ David Schley ${ }^{1}$, Jake Rice ${ }^{5 t}$ and Rohan J. C. Currey ${ }^{1+}$
}

\begin{abstract}
1 Department of Science and Standards, Marine Stewardship Council, London, United Kingdom, ${ }^{2}$ Centre for Ecology and Conservation, University of Exeter, Penryn, United Kingdom, ${ }^{3}$ Department of Biology, Dalhousie University, Halifax, NS, Canada, ${ }^{4}$ Department of Science and Standards, Marine Stewardship Council, Singapore, Singapore, ${ }^{5}$ Science Branch, Fisheries and Oceans Canada, Ottawa, ON, Canada
\end{abstract}

Illegal, unreported and unregulated (IUU) fishing activities threaten marine biodiversity, livelihoods, food security, and human rights across the globe. Often occurring in waters that are difficult to control, and across multi-sector, transboundary, value chains that are hard to regulate, such a complex and heterogeneous problem requires multiple strategies beyond sovereign nations' legislation alone. Here we explore the mechanisms through which eco-certification, by fostering private-public and crossjurisdiction cooperation, can incentivize fishers to adopt best practices in harvesting and ecosystem impacts mitigation, increase the transparency of fishery operations and accountability to suppliers. The Marine Stewardship Council (MSC) sets globally recognized standards for fisheries sustainability and supply chain assurance, based on the FAO Code of Conduct for Responsible Fisheries. Building on the MSC experience of over 400 certified fisheries representing 18\% of global wild marine catch, we analyze examples and available information on the changes achieved by the seafood industry through engagement with the program, with particular focus on the elimination or reduction of illegal, unreported or unregulated fishing practices. We propose here that different, interlinked mechanisms come into play: the Standards provide best practice guidelines for improved catch documentation, monitoring, control and surveillance (MCS), and strengthening regulations. These lead to change either through (1) direct improvements required for fisheries to achieve the certificate (e.g., in Fishery Improvement Projects) or, (2) once certified, to maintain the certificate, or (3) as an emergent effect of the engagement process itself, requiring stakeholder cooperation and transparent information-sharing leading to a greater culture of compliance, and (4), as an effect of strengthening chain of custody documentation and standardizing it across jurisdictions. We also discuss limitations, such as the capacity for fisheries 
in low-income regions to embark on the management and social reform required, and evolving challenges in seafood sustainability, such as ethical concerns for forced and child labor and shark finning. While not the single silver bullet against such a complex problem, we argue that certification is an important tool in addressing IUU fishing.

Keywords: MSC, monitoring control and surveillance, IUU, market incentives, value chains, fishery improvement projects

\section{INTRODUCTION}

The global decline in biodiversity is well documented (IPBES, 2019), with growing international calls for stronger conservation and its more sustainable use (WWF, 2018; IUCN, 2019; Secretariat of the Convention on Biological Diversity [SCBD], 2020). Commercial fisheries have consistently been identified as a main driver of declines in marine biodiversity (IPBES, 2019), with illegal, unreported and unregulated (IUU) fishing being a persistent factor in unsustainable fisheries (Cabral et al., 2018). IUU fishing is also associated with organized crime, including slave and child labor, widespread fraud and corruption (Mackay et al., 2020).

Rather than opting for a purely conservation-oriented approach $^{1}$, the strategy laid out for example through the UN Sustainable Development Goals (SDGs) places the problem in the context of the needs for global food security, livelihoods and societal well-being, setting targets for improving the sustainability of fishing (e.g., SDG142), rather than abandoning the practice (UN World Food and Agriculture Organization [FAO], 2020a).

Substantial guidance and policy frameworks are available to promote fisheries sustainability (FAO Code of Conduct for Responsible Fisheries; UN World Food and Agriculture Organization [FAO], 2001), yet the growing global demand for seafood continues to incentivize practices that evade resource management regulations or exploit their absence. IUU practices are found in all types and sizes of fisheries, occurring both on the high seas and in areas within national jurisdiction (Macfadyen et al., 2016).

Illegal, unreported and unregulated fisheries emerge where there are gaps or 'gray areas', in jurisdictional competencies, and where Monitoring, Control and Surveillance (MCS) systems are weak. These provide opportunities to circumvent regulations, for example through use of 'flags of convenience,' i.e., vessels switching registration to countries that are not signatories of international agreements, or transshipments of illegal catches to transport them outside of national jurisdiction and/or avoid local landing regulations (UN World Food and Agriculture Organization [FAO], 2016a).

While these vulnerabilities in the regulatory framework provide the opportunity, economic incentives or lack of alternative revenues often drive IUU fishing (Macfadyen et al., 2016). Market exclusion of seafood sourced from IUU fisheries can remove this incentive, provided catch from legal and well

\footnotetext{
${ }^{1}$ www.end-of-fishing.org

${ }^{2}$ https://sdgs.un.org/goals/goal14
}

managed sources can be effectively distinguished, and the supply chain does not allow substitution or mislabeling of IUU catch.

The 2001 International Plan of Action to Prevent, Deter and Eliminate Illegal, Unreported and Unregulated Fishing (IPOAIUU) summarizes the range of necessary strategies as: "The key to success in reducing and eventually eliminating IUU fishing is the adoption, application and enforcement of strong flag, coastal, port and market state regulation" (UN World Food and Agriculture Organization [FAO], 2001). As part of the marketrelated solutions, the Port State Measures Agreement (PSMA), is the first legally binding measure of its kind, intended to stop IUU catch from being landed and encourages States to work with commercial enterprises to penalize trading of IUU catch (UN World Food and Agriculture Organization [FAO], 2016a).

Though these strategies have been articulated with a focus on State regulatory responsibilities, successful reform requires the participation and buy-in of the actors involved in fishing and trading seafood (e.g., UN World Food and Agriculture Organization [FAO] (2020a) mentions "enforce deterrent sanctions. This includes [...] from the first point of sale through the whole trade chain, so that consumers and value chains also are motivated to accept only legally caught fish products"), and their coordination beyond single jurisdictions (e.g., UN World Food and Agriculture Organization [FAO] (2020b) states "This RPOA-IUU aims to combat IUU fishing in the WECAFC area of competence through effective regional cooperation among the WECAFC Member States"). Here is where private, multi-stakeholder initiatives such as eco-labeling have a role to play. Eco-certification is an increasingly widely applied tool for incentivizing best practice adoption in fishing and seafood industries, using the label recognition to give improved market access to sustainable fisheries (Certification and Ratings Collaboration [CRC], 2018). Seafood certification and ecolabelling programs such as the Marine Stewardship Council (MSC), one of the most established, are founded on the assumptions, or 'theory of change,' that adding value to sustainably harvested seafood, through a robust certification process and assured chain of custody $(\mathrm{CoC})$, induces selfreinforcing positive interactions between consumers, market actors, and industry (Arton et al., 2020). This positive feedback loop is assumed to incentivize more fisheries to make improvements that align with best sustainable practices (Komives et al., 2019; Arton et al., 2020; van Putten et al., 2020).

Here we argue that programs like MSC provide an effective set of mechanisms of achieving the goals set out in the IPOA-IUU by offering a pathway to guide and incentivize improvement toward well documented, well managed harvest practices, helping strengthen private/public sector cooperation, 
and bridging jurisdictional gaps across transboundary fishing resources and supply chains. While studies on the MSC or other eco-certification schemes are typically viewed in the context of fisheries that operate legally within well-monitored and managed frameworks, here our focus is the potential contributions that the presence of best practice guidelines provided by the MSC Fisheries and Chain of Custody (CoC) Standards and the market and reputational recognition offered by eco-certification, can make to addressing illegal, unreported and unregulated (IUU) fishing.

This overview is intended to capture 20 years of MSC's experience of working with multiple stakeholders, reflecting practitioner knowledge not easily documented in academic literature, in order to identify strengths and weaknesses in contributing to eliminating IUUs. We also discuss limitations of this type of tool, and remaining knowledge gaps. We conclude by discussing ongoing and imminent challenges facing not only the MSC program, but all seafood and marine sustainability initiatives.

\section{DIRECT AND INDIRECT EFFECTS OF THE MSC PROGRAM}

The MSC program plays a direct part in addressing Illegal, Unregulated and/or Unreported practices by providing best practice guidelines, based on the FAO Code of Conduct for Responsible Fisheries (Agnew, 2019), laid out in the Performance Indicators (PI) under each of the three Fisheries Standard Principles (P). These Principles address how fisheries are managed, how catches are reported and monitored for target (P1), bycatch and incidentally encountered species, as well as other ecosystem impacts (P2), and effectiveness of governance structures, decision-making mechanisms and enforcement (P3) (Table 1). Fisheries strive to comply with such requirements either in order to meet improvement targets and potentially become certified, or, once certified, in order to retain their certificate.

In addition to these explicitly set targets, IUU practices may be reduced as an indirect result of better coordination, cooperation and culture of compliance engendered by some of the Fishery and Chain of Custody $(\mathrm{CoC})$ requirements, and by the public and transparent process of the audit itself (Table 1). In addition, strict limitations on the scope of fisheries eligible for certification e.g., excluding anyone convicted for shark finning or slave labor (section 7.4, Marine Stewardship Council [MSC], 2020a), can indirectly put pressure on uncooperative 'bad actors' because harvester groups will have an incentive to exclude them from the certificate, and from ensuing economic benefits (Table 1).

\section{Fisheries in Improvement Toward Sustainability}

One of the common challenges preventing fisheries from getting certified is failure to meet the Fisheries Standard requirements due, for example, to absence of enforcement and inability to deter illegal practices in the fishery (Stratoudakis et al., 2015b). Though many fisheries around the world are still far from meeting
MSC sustainability requirements, the benefits of certification can motivate less well-managed fisheries to embark on a pathway to sustainability. The Fisheries Standard itself is often used as a tool to perform a gap analysis in fisheries that do not yet meet the standard, to prioritize improvements, whether with MSC certification as an end goal or not, using MSC's pre-assessment process and employing a suite of improvement tools (Marine Stewardship Council [MSC], 2019a). The greatest improvements in certified fisheries have been found to occur in the years leading up to entering the program (Martin et al., 2012), including improved governance and data collection (Bellchambers et al., 2016; Travaille et al., 2019). This provides an important mechanism to improving global fisheries sustainability and reducing IUU fishing, considering a quarter of the world's (reported) fisheries' catch is either certified or stated they are working toward MSC certification through improvements projects (Certification and Ratings Collaboration [CRC], 2018). A fishery improvement project (FIP) sets out formal plans for how the fishery will work, with the support of business, NGOs and other stakeholders, to attain a consistently high level of performance.

Some fisheries have used a combination of the MSC gap analysis, market demand for certified seafood and the FIP process to undertake actions to address IUU related issues such as through implementing measures to monitor and track IUU levels in the Barents Sea cod fishery (Steering Committee of the State of Knowledge Assessment of Standards and Certification [SCSKASC], 2012; SFP, 2012); assessing IUU levels and facilitating engagement with compliance authorities on plans to address illegal fishing in the Bahamas lobster fishery (Sullivan-Sealey, 2011; Travaille, 2020) and installing Vessel Monitoring Systems (VMS) and developing observer expertise on vessels in the Guyana seabob fishery (iNewsGuyana, 2015). Implementation of these activities led to improvements and ultimately to certification. In addition to formalized FIPs, progress may also be delivered through informal collaborations with government and stakeholders (Conservation Alliance for Seafood Solutions [CASS], 2019; Travaille et al., 2019), as in the case of the Suriname seabob fishery (ISEAL, 2017).

There are likely to be more examples of fisheries that started their improvement journey from a state of serious failures in regulation, documentation and compliance. But these are less likely to voluntarily publish their performance, for example, in self-reporting web platforms such as FisheryProgress ${ }^{3}$ (but see also Cannon et al., 2018).

Even the simple quantification of illegal catch, regionally as well as globally, has been fraught with methodological challenges and debate to overcome the gaps and anecdotal nature of the evidence (Gavin et al., 2010; Hilborn et al., 2019 in response to Pramod et al., 2019; Donlan et al., 2020 and references therein). Thus, in the following section, we rely on the records of fisheries in the MSC program to discuss where eco-certification offers behavioral incentives and mechanisms that deliver positive change - we argue that these same incentives and mechanisms

\footnotetext{
${ }^{3}$ fisheryprogress.org
} 
TABLE 1 | Conceptual overview summarizing the different mechanisms, direct and indirect, through which the MSC program can incentivize practices that prevent, deter, and eliminate IUU fishing, detailing the program components, the actors involved, the activity within the program, and the types of outcomes observed.

\begin{tabular}{|c|c|c|c|c|c|c|c|c|c|c|c|}
\hline \multirow{3}{*}{$\begin{array}{l}1 \\
\text { Stage } \\
\text { Actors }\end{array}$} & \multirow{2}{*}{\multicolumn{3}{|c|}{$\frac{\text { Direct effects }}{\text { Pre-certification (FIPs) or during certification }}$}} & \multicolumn{8}{|c|}{ Indirect effects } \\
\hline & & & & \multicolumn{4}{|c|}{ Pre-certification (FIPs) or during certification } & \multirow{2}{*}{$\begin{array}{l}\text { Audit } \\
\text { Fishers/ } \\
\text { Managers }\end{array}$} & \multicolumn{3}{|c|}{ During certification } \\
\hline & \multicolumn{3}{|l|}{ Fishers } & \multicolumn{2}{|l|}{ Fishers/ Managers } & $\begin{array}{l}\text { Fishers/Supply } \\
\text { chain }\end{array}$ & $\begin{array}{l}\text { Supply chain } \\
\text { actors }\end{array}$ & & Fishers & \multicolumn{2}{|c|}{ CoC/Fishery certificate holders } \\
\hline \multirow[t]{2}{*}{$\begin{array}{l}\text { MSC } \\
\text { components }^{2}\end{array}$} & \multicolumn{3}{|c|}{ Fisheries standard } & \multicolumn{2}{|c|}{ Fisheries standard } & \multicolumn{2}{|l|}{ CoC standard } & $\begin{array}{l}\text { Fishery public } \\
\text { reports }\end{array}$ & \multicolumn{3}{|c|}{ Fishery/CoC certification scope } \\
\hline & P1 & $P 2$ & P3 & $P 1, P 3$ & P3 & P3 & $P 2,3,4,5$ & $\begin{array}{l}\text { Audit and public } \\
\text { comment } \\
\text { stages }\end{array}$ & $\begin{array}{l}\text { no shark } \\
\text { finning }\end{array}$ & $\begin{array}{l}\text { no IUU } \\
\text { fishing }\end{array}$ & $\begin{array}{l}\text { no forced or } \\
\text { child labor }\end{array}$ \\
\hline Illegal & $\begin{array}{l}\text { Accounting of } \\
\text { illegal catch in } \\
\text { target species } \\
\text { assessments/ } \\
\text { control rules* }\end{array}$ & $\begin{array}{l}\text { Improved } \\
\text { estimates of } \\
\text { illegal retained } 5 \\
\text { incidental/ } \\
\text { bycatch spp* }\end{array}$ & $\begin{array}{l}\text { MCS } \\
\text { system detects } \\
\text { illegal activities* }\end{array}$ & $\begin{array}{l}\text { Clear evidence } \\
\text { for decision- } \\
\text { making* } \\
\text { creates trust } \\
\text { and compliance }\end{array}$ & $\begin{array}{l}\text { Inclusive } \\
\text { decision- } \\
\text { making* } \\
\text { creates trust } \\
\text { and compliance }\end{array}$ & $\begin{array}{l}\text { Illegal catch } \\
\text { excluded from } \\
\text { supply chain at } \\
\text { sea }\end{array}$ & $\begin{array}{l}\text { Illegal catch } \\
\text { excluded from } \\
\text { supply chain }\end{array}$ & $\begin{array}{l}\text { Transparent and } \\
\text { inclusive } \\
\text { mechanism to } \\
\text { raise issues } \\
\text { about illegal } \\
\text { catch }\end{array}$ & $\begin{array}{l}\text { Market } \\
\text { exclusion of } \\
\text { illegal (or } \\
\text { unethical) } \\
\text { operators }\end{array}$ & $\begin{array}{l}\text { Market } \\
\text { exclusion of } \\
\text { IUU } \\
\text { blacklisted } \\
\text { operators }\end{array}$ & $\begin{array}{l}\text { Market } \\
\text { exclusion of } \\
\text { illegal (or } \\
\text { unethical) } \\
\text { operators }\end{array}$ \\
\hline Unreported & $\begin{array}{l}\text { Improved catch } \\
\text { estimate of } \\
\text { target species }\end{array}$ & $\begin{array}{l}\text { Improved catch } \\
\text { estimates of } \\
\text { retained }^{4} / \\
\text { incidental/ } \\
\text { bycatch spp* }\end{array}$ & $\begin{array}{l}\text { Improved MCS } \\
\text { generates new } \\
\text { data* }\end{array}$ & $\begin{array}{l}\text { Coordinated } \\
\text { monitoring and } \\
\text { enforcement } \\
\text { efforts, across } \\
\text { jurisdictions, } \\
\text { improve likelihood } \\
\text { of detection }\end{array}$ & & $\begin{array}{l}\text { Unreported catch } \\
\text { excluded from } \\
\text { supply chain at } \\
\text { sea }\end{array}$ & $\begin{array}{l}\text { Unreported } \\
\text { catch excluded } \\
\text { from supply } \\
\text { chain }\end{array}$ & $\begin{array}{l}\text { Open } \\
\text { information } \\
\text { sharing from } \\
\text { managers, } \\
\text { fishers, NGOs, } \\
\text { etc. }\end{array}$ & & & \\
\hline Unregulated & $\begin{array}{l}\text { Improved target } \\
\text { stock } \\
\text { management }\end{array}$ & $\begin{array}{l}\text { improved } \\
\text { management of } \\
\text { retained }{ }^{4} / \\
\text { incidental/ } \\
\text { bycatch spp }\end{array}$ & $\begin{array}{l}\text { Jurisdictions } \\
\text { develop full } \\
\text { regulatory } \\
\text { frameworks }\end{array}$ & $\begin{array}{l}\text { Transparent } \\
\text { dispute- resolutior } \\
\text { and cooperative } \\
\text { management* of } \\
\text { transboundary/ } \\
\text { RFMO stocks } \\
\text { removes loophole }\end{array}$ & & $\begin{array}{l}\text { Interoperative chain } \\
\text { of custody } \\
\text { documentation } \\
\text { helps close } \\
\text { loopholes across } \\
\text { catch } \\
\text { documentation } \\
\text { jurisdictions }\end{array}$ & & $\begin{array}{l}\text { Information } \\
\text { exchange leads } \\
\text { to reciprocal } \\
\text { trust and } \\
\text { accountability }\end{array}$ & & & \\
\hline
\end{tabular}

The reference to specific components of the Fisheries Standard is further elaborated in Supplementary Table 1.

${ }^{1}$ Acronyms and symbols: MCS, Monitoring Control and Surveillance; CoC, Chain of Custody; P, Principle; *, relevant conditions found in condition analysis (see Supplementary Table 1).

${ }^{2}$ Referring to requirements, scope and audit guidelines laid out for Fisheries Standard v. 2.1, Chain of Custody (CoC) Standard v.5.0, Fishery Certification Process v. 2.2.

3 In addition to excluding shark finning fisheries from certification, requirements on finning are also present under Principle 1 for shark fisheries applying for certification.

"Since 2019 this includes additional requirements for cases needing on-site third-party labor audits, specified in "MSC Third-Party Labour Audit Requirements" v. 1.0.

${ }^{5}$ 'Retained' species are landed by the fishery but not the 'target' populations assessed (or pre-assessed) under Principle 1 for carrying the MSC ecolabel. 
are likely to be at play also in fisheries at the start of the improvement journey.

\section{Fisheries Improving Once Certified}

As stated in guidance for auditors, "In relation to IUU, the MSC intention is that UoAs [Unit of Assessment] be harvested legally and that IUU is non-existent, or where IUU does exist it is at a minimum level such that management measures, including assessments and harvest control rules and the estimation of IUU impacts on harvested species and the ecosystem, are capable of maintaining affected populations at sustainable levels" (Marine Stewardship Council [MSC], 2018). Certified fisheries must comply with all national and international law, and IUU fishing should be clearly considered in assessments and included in documentation of unobserved mortality (Marine Stewardship Council [MSC], 2018). To be certified, the MSC Fisheries Standard instructs that ecosystems and fish stocks must not be suffering detrimental impacts from IUU fishing, even if it is caused by others (Marine Stewardship Council [MSC], 2018). Further, vessels listed on IUU blacklists are not permitted to be used for catching or transporting fish (Marine Stewardship Council [MSC], 2019b), aligning with the IPOA-IUU strategies (UN World Food and Agriculture Organization [FAO], 2001).

As a result, a group of fishers would not pass the certification audit if operating illegally, or if they were catching a population with no management of sustainable harvest. The MSC program does allow 'conditional' certification of fisheries that, for a limited number of Performance Indicators (PIs) under each of the three Principles, meet minimum sustainability requirements (i.e., 60 score) but not yet best practice (i.e., 80 score). Such fisheries retain their certificate if they address the 'conditions' through time-bound explicit milestones in an action plan, monitored during surveillance audits. These certified entities represent a sample of best performing actors, that, if they did have any issues in their past, are now taking the last steps in a set of incremental changes to arrive at best practice. Though these are not fisheries riddled with multiple and egregious IUU behaviors, the certificate reports documenting progress on such 'conditions' provide explicit and systematic reporting of changes on well-defined issues. This can be indicative of the range of activities less performant fisheries, lacking a similarly standardized and detailed record, undertake in making strides toward legal, well-regulated and well-documented management.

An analysis of the text describing conditions' rationale, action plans or milestones (Supplementary Table 1), shows how all three Fisheries Standard Principles can be associated with improved practices or mitigation of illegal, unregulated and unreported fishing (Table 1, fields under 'Fisheries Standard Requirements'). The analysis highlighted many examples of fisheries with recent conditions across four themes: reporting of 'Illegal catch estimates' for the population considered under the certificate, 'Reporting' of legally required information for other species captured, inclusive and/or 'Transparent decisionmaking, and effective Monitoring Control and Surveillance ('MCS') systems (Supplementary Tables 2, 3).
Principle 1 requires, among other things, that information is available on illegal catch estimates of the stock being evaluated for certification, even if these are due to other harvesters. Fisheries have attracted conditions to address this issue across different Principle 1 PIs, because correct estimates of removals feed into the status assessment of the population (PI 1.2.4), can be determined through monitoring (PI 1.2.3) and are part of the key sources of uncertainty to consider when evaluating if harvest control rules are robust (PI 1.2.2) (Supplementary Table 1). For example, the Lake Peipus perch and pike-perch certificate requires that the fishery "Design a scientifically valid approach to determine the sources and amounts of pikeperch mortality associated with recreational and IUU fishing" as one of its action plan Milestones for a condition on PI 1.2.4. The harvester group that holds the certificate are not responsible for those fishing activities, but those removals must be accounted for to have a correct assessment. Similar improvements were requested of the Bratsk Reservoir perch fishery, with an explicit outcome being managers' transparent documentation and justification for how IUU catches are estimated. The action plans often explicitly require producer associations to work collaboratively with institutions (e.g., "meet with fishery managers to review data, discuss uncertainties, and consider modifications to the stock assessment methods." States the Lake Peipus 3rd Surveillance Milestone for condition on PI 1.2.4), in some cases across jurisdictional powers (e.g., Estonian and European monitoring of Lake Peipus), adding a new layer of transparency to the institutions' own activities.

All the other species that are caught by the fishery but are not being assessed to potentially carry the ecolabel are evaluated under Principle 2, whether targeted, retained or discarded bycatch, or incidental catches and interactions with Endangered Threatened and Protected species (ETPs) (Table 1). It is often the case that species with low or no commercial value are inconsistently monitored, resulting in patchy knowledge of fishing impacts and populations status. Yet, this information is often required by law and vital to managing and conserving these species (Lewison et al., 2004; Agnew et al., 2009). It is no surprise that a high proportion of conditions raised for Principle 2 requirements are around improved monitoring and reporting of such species (Marine Stewardship Council [MSC], 2016, 2020b). MSC requires that information is provided regardless of whether it is legally mandated by local management regulations. Even when filtering only for those cases mandated by law, so as to meet the commonly understood definition of 'unreported' catch, there are a broad range of examples of improved reporting of intentional or incidental catches, from sharks, to finfish to marine mammals (Supplementary Tables 1, 2). In the Australian Eastern Tuna and Billfish Fishery the concern was actually about the status of the Argentine squid stock used as bait in the fishery. In this case the fishery committed to either ascertain that the presence of IUU squid fishing isn't threatening its sustainable harvest, or, if this cannot be confirmed, to seek a different source of bait. In other cases, the condition requires establishing a new monitoring program to ensure a sustained source of information, such as the Cornish hake or Poole Harbor clam and cockle fisheries (Supplementary Table 1). 
If a fishery needs to demonstrate there are no "Unreported" or "Unregulated" activities, and there is effective enforcement of regulations, this will often result in conditions on strengthening MCS systems under Principle 3 (Table 1), specifically for PI 3.2.3 (Supplementary Table 1). The Western Asturias Octopus Traps Fishery of Artisanal Cofradias, for example, was first certified on condition that it would address reported non-compliance in the number of octopus traps used by some fishermen. Since then, the Asturias administration has implemented that gear are marked as a pre-condition to obtain the octopus fishing license and now $100 \%$ of vessels are marked and found compliant. The condition also required that by the Third Surveillance Milestone "Evidences that enforcement capacity has been improved shall be provided." Since then, satellite tracking has been installed on all the vessels included in the certificate and the government committed to purchasing a new addition to the patrol fleet. The latest public draft report marks the condition as having been met (González et al., 2021).

In addition to these direct improvements, conditions can also drive improvements indirectly (ISEAL, 2017). This can happen when, for example, the effort to fulfill them results in increased cooperation across stakeholders, or transboundary institutions, or increased transparency and inclusivity of the governance process, thus increasing institutions' accountability, social license, and fishery participants' culture of compliance.

\section{Indirect Effects: Building a Culture of Compliance and Stakeholder Cooperation}

Giving all the parties involved in the fishery the ability to be engaged and consulted in operational decisions can be effective in reducing IUU fishing by creating a culture of compliance, as it builds legitimacy and establishes normative behaviors (Jagers et al., 2012; Pomeroy et al., 2016). Principle 3 requirements of the Fisheries Standard are designed so that a robust regulatory system goes hand in hand with an inclusive and transparent process.

For example, the PNG Fishing Industry Associations purse seine Skipjack and Yellowfin Tuna Fishery was asked to "undertake improvement in prescribing a process for multistakeholder efforts in the tuna technical advisory consultative committee setup and their full participation in regards to any program or activity that aims to improve the management and development of the tuna fisheries," to close a condition on PI 3.1.2 (consultation roles and responsibilities). On the other hand, conditions on PI 3.2.2 (decision-making processes) require a clear and documented process for taking decisions, thus creating accountability for governing institutions. For example the American Samoa EEZ Albacore and Yellowfin Longline Fishery is required to provide, as an action plan milestone "some evidence that the Commission is responding to the issue of SP albacore catch rates."

It is worth noting here that the MSC Fisheries Standard is not prescriptive on the governance structure in use, so that PI 3.1.1, for example, refers to 'legal and/or customary frameworks' so as to recognize different types of management frameworks, including 'accepted practice' and acknowledging the range of actors that can take part in such frameworks may include e.g., producer associations and indigenous groups (GSA 4.3 in Marine Stewardship Council [MSC], 2018).

Increased transparency, cooperation and trust may even result from the certificate audit itself (Table 1). The MSC Fisheries certification process requires that a third party auditor identify and bring together all sources of information and expertise so as to generate evidence to benchmark the fishery. This is done both by meeting groups of stakeholders, for example to identify data that are harder to locate from a desk-based scan, or through online publication of draft reports that are opened to public comment on the MSC website (Brown et al., 2016). Different stakeholders have the opportunity to see what information others have submitted, and must provide supporting evidence for their respective positions. The need for public documentation has helped illuminate shortcomings in data reporting by Western Australia (WA) fishery management that have since been addressed, resulting in increased knowledge sharing between managers and stakeholders (Bellchambers et al., 2016). Additionally, successful MSC certification for several WA State-managed fisheries ensured management institutions earned greater stakeholder trust (Bellchambers et al., 2016; van Putten et al., 2020; Robinson et al., 2021). This greater transparency, has led to strengthened institutional accountability, for example in South Africa, following the process of certification of the cape hake (Merluccius capensis) (Butterworth, 2016). Stratoudakis et al. (2015a) noted that use of a tool like the MSC Fisheries Standard means that stakeholder debate can focus more on finding solutions than on being divided on problems, since it allows benchmarking against an external, standardized framework.

Improved regulatory structures, increased compliance and exclusion of IUU operators often is built through incremental changes.

The Ben Tre hand gathered clam fishery in Vietnam, certified since 2009, is operated by local cooperatives of fishers who are involved in harvest, surveillance, and management of their areas. The goal of maintaining MSC certification for the Ben Tre fishery has reenforced collaborations with government agencies for strengthening regulations (Xuan and Seip-Markensteijn, 2019). The initial certification of the fishery required to meet a condition on regular external reviews of the sustainability of the fishery management structure. Based on the recommendations of the first review (Akroyd and Luu, 2013), local governments became more involved in solving or escalating issues of illegal fishing, patrolling by the Coast Guard and local police, and effectively sharing information on illegal activity between agencies and with cooperatives (Gascoigne et al., 2016). The province of Ben Tre has also announced a focus on installing tracking devices on fishing vessels to further monitor and reduce IUU fishing (Vietnam News Agency [VNA], 2020). Thus, beyond the incentive for compliance from the actors involved, pressure was added on non-compliant actors by taking initiatives to exclude them from the value chain. Building on these positive outcomes, in 2018, a 4-year EU-funded Oxfam project was launched, aiming at 
increasing the ability of small- scale producers to negotiate for their position in the value chain, reinforcing the incentive to maintain certification (Vietnam News Agency [VNA], 2018; Xuan and Seip-Markensteijn, 2019).

\section{Incentivizing Multi-National Cooperation in Managing Transboundary Resources}

When it comes to transboundary stocks or stocks managed through Regional Fisheries Management Organizations (RFMOs), it is notoriously difficult for political interests of all invested parties to align to reach a consensus on precautionary management, especially if there isn't an imminent threat to stock productivity. Indeed shared stocks appear to be declining more than other fisheries (Palacios-Abrantes et al., 2020), and, ever since the IPOA-IUU was first established, high seas and RFMO fisheries have remained a key focus of efforts to end IUU practices. In the case of Indian Ocean skipjack tuna (Katsuwonus pelamis), combined pressure from large retail brands sourcing tuna, NGOs (i.e., WWF), and harvesters interested in maintaining their certificate [Maldives Seafood Processors and Exporters Association and the International Pole and Line Foundation (IPNLF)], helped tip the balance toward all coastal states in the Indian Ocean Tuna Commission (IOTC) agreeing to 'well-defined harvest control rules' that met MSC requirements (Indian Ocean Tuna Commission [IOTC], 2016). This example illustrates how certification can provide an additional push to get stronger RFMO regulations over the finish line.

The WPSTA Western and Central Pacific skipjack and yellowfin free school purse seine received conditions under Principle 3 requiring improvements in MCS and transparency. The action plans developed to address them require that the certificate holders put pressure on the WCPFC RFMO member states to cooperate on issues such as data sharing, "evidence of flag state enforcement and controls on vessels fishing in the WCPFC Convention Area.", and engage in specific activities, such as "WPSTA will request meetings with China Overseas Fishery Association (COFA) to understand the most recent Compliance Monitoring Report (CMR).”

In some cases the necessary cooperation for a cohesive regulations of shared stocks is hard to reach and the fishery can see its certificate suspended as a result, such as the ISF Iceland mackerel fishery (Marine Stewardship Council [MSC], 2021; Supplementary Table 2).

\section{SUPPORTING TRANSPARENT AND TRACEABLE SUPPLY CHAINS}

One of the key strategies recommended in the IPOA-IUU, and in the many regional plans that followed since (e.g., UN World Food and Agriculture Organization [FAO], 2020c), is to achieve transparency and traceability throughout seafood supply chains. Traceability, or the collection and verification of information on the product's origin and movements, has gained increasing prominence in its ability to support efforts to prevent IUU products reaching markets. Examples of such efforts include the European Union Catch Certification, or the US NOAA 2018 Seafood Import Monitoring Program. The MSC is an example of a non-regulatory market measure. MSC traceability reporting checks begin at sea. To demonstrate legality, key data elements, such as the species or stock, gear type(s), catch location, quantity, crew information and vessel registration may be required. Information on origin can be collected by human observers, cameras, or automatic identification systems (AIS), though these are not legally required in many fisheries and seafood supply chains. In such cases paper records such as logbooks, catch certificates and landing declarations are common, but they are open to manipulation which is a risk considered in the MSC audit. Typically, they do not document information on catch movement such as transfers from harvest to transshipment vessels and the offloading in port to thirdparty sale agents, so they may prevent from demonstrating a product's 'CoC' and thus origin. A fishery assessor will determine whether the systems are sufficient to prevent mixing, substitution and misreporting, and publish their determination on the MSC website $^{4}$ for transparency. From this point onward, all actors in the supply chain that wish to trade products that can carry the MSC ecolabel must have a valid MSC Chain of Custody (Marine Stewardship Council [MSC], 2019b) certificate (Figure 1). The Chain of Custody Standard sets out requirements, including where there may be a risk of IUU fishing, to ensure certified products are effectively segregated from non-certified with each internal movement tracked and every transformation reconciled through an auditable record trail. A CoC certificate holder cannot source product from vessels on RFMO blacklists for IUU fishing (Marine Stewardship Council [MSC], 2019b). The process provides assurance a product came from an MSC certified sustainable fishery for a particular species, though not which specific fishery, as it does allow mixing of catch from different certified sources.

\section{Closing the Gap: Strengthening Chain of Custody From Port to Processor}

One of the ways in which IUU fish can enter legal supply chains is through weak monitoring and controls during landing in ports. Salmon fisheries in the Sea of Okhotsk in the Russia Far East, an area historically associated with high levels of IUU fishing (Lajus et al., 2018), have taken steps to ensure that MSC certified salmon caught in Russian waters and landed in Russian ports could be assured as coming from a certified sustainable and legal origin. As an additional assurance that all data gaps are closed, the conformity assessment body (CAB) performing the audit evaluated both the fishery and the first buyers with $\mathrm{CoC}$ certificates. The fishery assessment for the Zarya-Kolpakovsky Sobolevo West Kamchatka Salmon fishery included a review of product flow from catch to arrival at the processing facility and describes the efforts by companies in the fishery certificate to "enhance enforcement activities by supplying personnel, equipment, and funding to the authorities" to minimize the opportunity for illegal harvest in the beach regions and rivers where illegal fishing and harvest of salmon roe occur

\footnotetext{
${ }^{4}$ fisheries.msc.org
} 


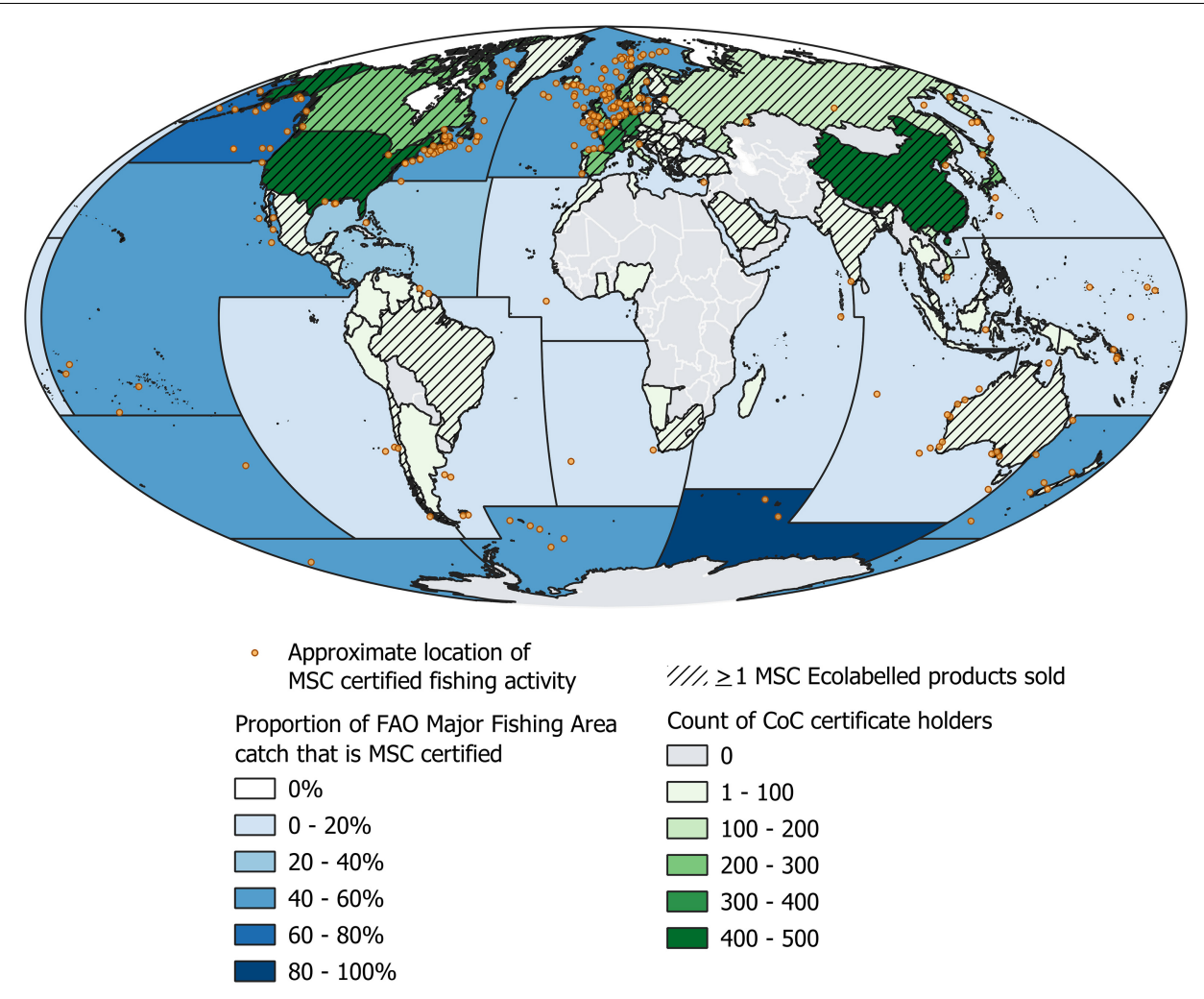

FIGURE 1 | Global distribution of MSC certificate holders at sea (fisheries) and on land (supply chain) and consumer-facing ecolabelled products sold. Count of Chain of Custody (CoC) certificate holders per country as of 15 September 2020, eco-labeled products sold from 1 April 2019 through 31 March 2020 , certified fishery reported landings as of 31 March 2020 as a proportion of FAO 2018 marine capture per FAO major fishing area (UN World Food and Agriculture Organization [FAO], 2020d), excluding inland, farmed, plants and mammals. Approximate centroid point locations for MSC certified fisheries

(https://fisheries.msc.org/en/fisheries/) as of 31 March 2020. Data description available at Marine Stewardship Council [MSC] (2020b).

(MRAG Americas, 2020). The additional enhanced enforcements include restricted landing ports where documentations are crosschecked between landing and arrival at processing facilities to ensure a "robust $\mathrm{CoC}$ to mitigate the risk of product from a noncertified source entering the supply chain" alongside the various activities undertaken by the buyer to check the legal and certified status of each fishing parcel received at their facilities.

\section{Tamper-Proof Catch Data Transferred Along the Supply Chain}

The Convention for the Conservation of Antarctic Marine Living Resources (CCAMLR) was established to manage the Southern Ocean. Its mandate includes management of toothfish stocks (Dissostichus spp.). As an early participant in the MSC Fisheries program, significant efforts to eliminate IUU from the member states' fisheries were made to support the application for certification (Baird, 2005; Agnew, 2008).Vessel inspection results are shared with other member states to facilitate cooperation in enforcement actions. Catch Documentation Schemes (CDS), barcodes and satellite technology are used to capture tamper-proof information that is accessible by port states to monitor landings and ensure only legally caught toothfish can be landed and sold into legal supply chains.
CCAMLR maintains a public list of legal vessels, making it harder for vessels engaged in illegal fishing to land their catch and pass it off as legally caught. MSC Chain of Custody certification (Andrews and Medley, 2018) allowed for example the legal toothfish fishery in South Georgia to re-gain social acceptability after intense consumer awareness campaigns against illegal harvests had greatly reduced marketability for toothfish (van Putten et al., 2020; Robinson et al., 2021). CDSs can be used to fulfill customs control and document legal provenance of seafood products, and have common objectives to the MSC Chain of Custody certification, while not constituting a traceability system per se (UN World Food and Agriculture Organization [FAO], 2016b). As more countries and regions look to CDSs to protect their markets from IUU products, progress remains slow with varying levels of commitment and differences in approaches to implementation. CCAMLR's success is in part due to its multilateral approach, as evidence suggests that they can be more effective at reducing the benefits gained from IUU fishing (ICTSD). For example, without coordination and harmonization between the flag state and port state there may be inconsistency in what data are collected and how data are captured and reviewed. The Chain of Custody certification process, verifying the "custodial sequence that occurs as ownership or control of the material supply is transferred from one custodian to 
another in the supply chain," can be a driver to overcome this issue. The CoC Standard requires accurate documentation and reviews the capability of all businesses in a given supply chain to maintain it through periodic audits and ad hoc investigations. This closes data gaps from one jurisdiction's scheme to another while enhancing a level playing field by applying the same requirements to actors entering global markets from outside of import control schemes.

In addition, forensic techniques for product authentication such as DNA barcoding help close the net on IUU product laundering and seafood fraud in the supply chain. MSC conduct frequent product sampling for DNA testing, to detect species substitution and product mislabeling (Barendse et al., 2019) and is exploring use of genetic and stable isotope techniques to further trace seafood products' provenance back to specific areas or fish populations (Cusa et al., in review).

\section{BEYOND ENVIRONMENTAL CONCERNS: ETHICAL AND SOCIAL DIMENSIONS OF ECOLABELING}

As an incentive-based approach to improve fishing practices, it is important to consider the socioeconomic implications of environmental requirements.

\section{Socioeconomic, Environmental, and Ethical Issues in Shark Finning}

This emerges, for example, with regards to shark finning the practice of removing fins from sharks and discarding their bodies at sea - widely condemned due to its cruelty, wastefulness, and unsustainability (Spiegel, 2001) and illegal in many countries and RFMOs. The challenge facing sustainable seafood standard-setters is how to produce requirements that contribute meaningfully to shark conservation, avoid inequitable barriers to entry to the program, whilst also taking into consideration all views from diverse stakeholders on a highly emotive and polarizing issue.

Marine Stewardship Council does not allow shark finning certification in scope, while it provides requirements to regulate legal shark fisheries (Table 1). Fins can make up a large proportion of the income of fishers involved in sustainable shark fisheries, and blanket bans on selling shark fins, that do not distinguish if the source was from a legal or shark finning fishery, can negatively impact these fishers' livelihoods (Shiffman and Hueter, 2017; Simpfendorfer and Dulvy, 2017). Additionally, finning bans do not guarantee decreased shark mortality (Clarke et al., 2013), particularly where subsistence is the primary driver of shark mortality, as is common in low income communities (Dulvy et al., 2017; Glaus et al., 2018; Karnad et al., 2019), and could simply raise the market value in the black market fin trade. Lack of reporting further undermines conservation efforts that rely on accurate estimates of mortality (Edwards, 2006). Combining sustainable and well-managed shark fisheries with well-enforced finning regulations may ensure supply of legally and sustainably harvested fins, reducing the incentive for illegal, unsustainable harvests. Herein lies an opportunity for eco-certification to contribute significantly to eliminate the IUU component of these fisheries.

Current MSC information requirements contribute to addressing the gap in independently verified catch records, with 20 MSC fisheries having already made improvements mainly in monitoring and research of shark and ray bycatch (Supplementary Table 4). If evidence of shark finning is detected during an audit or assessment, a fishery will face suspension unless it can show the offending vessel has been expelled from the certificate. Yet, given the complex intersection of environmental concerns and socioeconomic constraints for this type of fishery, MSC is conducting global public consultations with stakeholders as part of the current MSC Fisheries Standard Review (Marine Stewardship Council [MSC], 2020c).

\section{Eliminating Forced and Child Labor}

Though MSC's focus has been on environmental sustainability, with social dimensions only covered regarding fair participation in fisheries governance, a zero-tolerance position was taken on forced and child labor.

A growing body of work points to a connection between illegal fishing and labor practices (Tickler et al., 2018; EJF, 2019; Mackay et al., 2020). As stocks become depleted and the costs of fishing increases, illicit operators attempt to improve margins through exploitative labor practices which then lead to worsened stock health and further labor abuses in a vicious cycle to maintain margins. Bioeconomic modeling of the feedback between environmental degradation from fishing activity and human rights demonstrates that reduced costs, enabled via human rights and labor abuses, can lead to environmental decline in fisheries (Lewis et al., 2017). Market based standard and audit tools can potentially contribute to eliminating forced labor and IUU practices. However, options to do this through certification standards are currently limited.

Marine Stewardship Council established that operations where there has been a conviction for egregious labor violations are 'out of scope', i.e., they are simply not eligible to hold a certificate. These provisions are not based on environmental sustainability principles. Rather, they are the expression of an ethical stance taken by the MSC Board of Trustees. To further support this intent, MSC recently added a requirement that at-sea operations self-report on mitigation measures. New requirements include that each Chain of Custody registered site is evaluated based on its activities and country's labor risk. Unless they are found to be low risk, sites must pass a third-party labor audit program in order to maintain their MSC certification.

Yet, this remains an area where best practice for effectively identifying these activities is still being developed. Indeed, only a small number of third-party auditing initiatives have been established to assess labor issues. Many are at early stages of development such as the Responsible Fishing Vessel Scheme (RFVS) (IntraFish, 2020), or only applicable to a specific subset of the industry - such as the Fairtrade USA Capture Fisheries Standard (Fair Trade USA [FTUSA], 2017). The efficacy of certification schemes to drive improved labor conditions 
in capture fisheries has been questioned (Praxis Labs, 2019). Perceived limitations include the complexities involved in undertaking comprehensive audits while vessels are at sea, the level of assurance that can be provided from labor audits conducted at port and resources required to undertake audits that provide acceptable levels of assurance. There is a need for better understanding of the practicality and effectiveness of standards and certification for labor practices. The compilation of selfdeclarations from all certified entities may provide a unique opportunity for a large-scale, standardized overview of the state of play (Tindall et al., in preparation), and a first step to build on for further action.

\section{DISCUSSION}

Just like other types of illegal wildlife harvest, IUU fisheries have serious environmental, social and economic consequences. Solutions must engage the full stakeholder community and work across the whole supply chain.

The international community has identified root causes of IUUs in the failure of appropriate regulatory mandates, particularly in high seas, weak enforcement of existing regulations, and appropriate documentation of activities at sea (and sometimes on land). These points highlight the resource and physical limitations of MCS, so that compliance needs to be incentivized in other ways. These may include cross jurisdiction cross national and cross sector collaboration, which can be beyond the reach of a single authority but accomplished when there is industry cooperation, such as the case of the MSC global network of certificate holders (Figure 1).

Here we compiled lessons learned from anecdotes, published peer reviewed and gray literature and analyses of MSC certificates, providing a perspective on the range of direct and indirect mechanisms through which the MSC program can incentivize change, across fisheries striving to meet best practice, or even once certified, in turn creating pressure for other harvester and supply chain companies to improve.

A perspective of how the MSC program helps address IUU fisheries we propose that, to address ILLEGAL fishing the main mechanisms offered by the MSC program include:

- The Chain of Custody requirements can prevent illegally caught fish from entering the certified product streams.

- Requirements for inclusive governance give a transparent and inclusive mechanism for stakeholders to raise issues about Illegal catch, and the fishery governance processes must provide transparent responses to concerns that are raised.

- The requirement that jurisdictions of shared stocks must share information can incentivize coordinated monitoring and enforcement efforts, improving likelihood for detection of illegal fishing.

- The requirements for effective MCS implementation, including catch documentation for all vessels, ensures appropriate systems of detection of illegal activities are put in place.
To address UNREPORTED fishing the main mechanisms in the MSC program include:

- Chain of custody and catch documentation provisions can prevent legal but unreported catch from entering the certified product stream.

- The necessity for segregating harvest from uncertified capture starting at sea, rather than at landing site, works with the chain of custody and catch documentation in further deterring unreported catch.

- By requiring jurisdictions of shared stocks to share information, incentives are provided for coordinating assessments and better detection of mis-reporting across jurisdictions.

To address UNREGULATED fishing the main mechanisms in the MSC program include:

- Fisheries working to meet the Fisheries Standard Principle 3 requirements can lead to strengthening regulatory processes. Particularly, this applies to requirements for explicit legal and/or customary frameworks for management, full definition of roles and responsibilities for all aspects of fisheries governance, explicit decision-making processes and evidence for enforcement and compliance.

- The need for sound assessments of stock status creates incentives for biologically based reference points, and, in turn, require jurisdictions to develop full regulatory frameworks, first to set reference points and harvest control rules, then to monitor their enforcement.

- The requirements for effective MCS implementation, including catch documentation schemes, help collect more comprehensive data to inform status assessments and set effective management reference points.

\section{Other Tools and Strategies}

There are circumstances where eco-certification may not be a highly effective tool.

By their very nature, IUU practices are difficult to document and monitor, which in itself may be a challenge to addressing them. New proposed methods may assist in using qualitative sources (Donlan et al., 2020), and emerging technologies (e.g., Global Fishing Watch, 2020), though these must consider ethical implications of data ownership (Toonen and Bush, 2020) and fair and inclusive definitions of legal frameworks and implementation of MCS systems (Song et al., 2020).

Despite the MSC Fisheries Sustainability requirements allowing for 'customary and informal legal frameworks', and use of non-conventional resource assessments (Marine Stewardship Council [MSC], 2016), or risk-based evaluations of impact in data limited cases, and though ongoing global outreach initiatives provide training on the MSC program and improvement tools in many languages, fishery certification occurs most often in northern Europe and north Americas (Figure 1). This geographic pattern is likely to reflect the interplay of socioeconomic, 
policy and market-related factors that are not favorable to the ecolabeling incentive model (at least not yet). For example, wildlife harvest targeted to specific traditional uses, such as shark fins or manta ray gill plates, is difficult to eradicate because it has a steady demand, it occurs in low-income communities, and bans can have the counterproductive effect of increasing its market price and thus the incentive to defy regulations (Shiffman and Hammerschlag, 2016; Booth et al., 2020). In these cases, all other challenges aside, certification is unlikely to provide a commensurate economic incentive. Even when wildlife is more valuable alive to attract tourism than traded as meat (Mustika et al., 2020), local communities excluded from that industry might see no better option than illegal fishing.

NGOs and grassroots organizations have been working on a range of strategies, from educating and raising awareness to reduce demand, to capacity building to strengthen enforcement, to campaigns for stronger trading regulations and seeking options for alternative livelihoods (e.g., the GSRI strategy ${ }^{5}$ ). Given the local nature of socioeconomic dynamics of wildlife harvest and the global nature of supply chain pathways, and multiple jurisdictions and actors involved, different tools will need to work together (Booth et al., 2020).

\section{Past and Future}

The MSC Fisheries Standard emerged in 1998 from the intent to operationalize the FAO Code of Conduct for Responsible Fisheries (Agnew, 2019). Both Fishery and Chain of Custody Standards have been reviewed and revised on a 5 -year basis, incorporating changes in scientific advice, as well as input from all the stakeholders that contribute to the program. In the last decade increasing attention has been placed on including human dimensions in fisheries management (De Young et al., 2008), and the seafood sustainability movement has embraced a more complex notion of sustainability interventions (Kittinger et al., 2017; Bush et al., 2018). It would seem a natural progression therefore that a program focused on environmental sustainability will also grapple with ethical issues such as human rights violations or complex socioecological tradeoffs such as shark finning. As stakeholders' expectations broaden, the program is asked to engage with legal and socioeconomic contexts that may reach beyond its area of influence, or require evolving toward innovative approaches, for example in creating a pathway to sustainability for the many fisheries that do not yet have the resources, capacity, data, and institutions to meet the MSC sustainability requirements (Marine Stewardship Council [MSC], 2019b).

Eco-certification with an assured chain of custody provides a range of direct and indirect mechanisms of addressing IUU practices. It can not only shift the financial incentive for illegal activities and fraud, but also facilitate a culture of compliance with existing regulations through increased dialogue with and trust in institutions. It requires fair and transparent data

\footnotetext{
${ }^{5}$ http://fscdn.wcs.org/2016/02/10/1cxcak0agd_GSRI_

GlobalPrioritiesForConservingSharksAndRays_web_singles.pdf?_ga=2.

112043584.596836061.1606895663-190274890.1606895663
}

sharing which improves reporting of information and can bolster stakeholder cooperation, in turn further reinforcing cultural compliance norms. Where regulations are absent or insufficient, it creates an incentive to improve the management framework, by aligning the interests of different stakeholders from harvesters, managers, local NGOs, to other actors all across the supply chain. It also provides a mechanism for industry, from harvester to supply chain actors, to fully document their activities within a cohesive framework, beyond what regulations are in place where the fish were caught, landed, transported, or sold.

Addressing IUU practices, especially on the high seas, or in low-income countries with weak institutions, is extremely difficult, and requires a range of strategies and organizations working on multiple fronts, from local grass-roots NGOs working for education and awareness, to institutional reform, in national and international policy fora to market-based incentives. The recent global covid-19 pandemic demonstrated global value chains can have serious impacts on local communities (Knight et al., 2020), but market mechanisms can also reach across the globe to generate positive change. We propose, based on the information and anecdotes available to date, that ecolabeling programs such as the MSC are one valuable intervention in a range of complementary tools that need to be brought together to bring us a step closer to eliminating illegal, unregulated 600 and unreported fisheries.

\section{DATA AVAILABILITY STATEMENT}

The datasets analyzed for this study were manually extracted from MSC fishery public certificate reports (PCRs) that can openly be accessed from https://fisheries.msc.org/en/fisheries/. The specific data analyzed and fisheries whose reports were used can be found in Supplementary Tables 2,3.

\section{AUTHOR CONTRIBUTIONS}

CL, RC, JR, OO, and DS ideated the work. CL, JR, OO, SL, LK, SYL, and LB wrote the first draft. All the authors edited the manuscript. CL, SG, TG, LK, and SL executed the data collection and analyses. CL created the tables. LK created the figure. All authors contributed to the article and approved the submitted version.

\section{ACKNOWLEDGMENTS}

We would like to thank Kate Dewar, Tim Davies and Stefano Mariani, and the two reviewers for helpful feedback on a draft version of the manuscript.

\section{SUPPLEMENTARY MATERIAL}

The Supplementary Material for this article can be found online at: https://www.frontiersin.org/articles/10.3389/fevo.2021. 637228/full\#supplementary-material 


\section{REFERENCES}

Agnew, D. J. (2008). “Case study 1: toothfish - an MSC-certified fishery," in Seafood Ecolabelling Principles and Practice, eds T. Ward and B. Phillips (Oxford: Wiley Blackwell), 247-258. doi: 10.1002/9781444301380.ch11

Agnew, D. J. (2019). Who determines sustainability? J. Fish. Biol. 94, 952-957. doi: $10.1111 / \mathrm{jfb} .13928$

Agnew, D. J., Pearce, J., Pramod, G., Peatman, T., Watson, R., Beddington, J. R., et al. (2009). Estimating the worldwide extent of illegal fishing. PLoS One 4:e4570. doi: 10.1371/journal.pone.0004570

Akroyd, J., and Luu, T. T. (2013). Surveillance Report Ben Tre Hand-Gathered Clam Fishery. Available online at: https://fisheries.msc.org/en/fisheries/vietnam-bentre-clam-hand-gathered/@@assessments (accessed November 13, 2020).

Andrews, J., and Medley, P. (2018). Public Certification Report for the South Georgia Patagonian Toothfish Longline. Available online at: https://isheries.msc.org/ en/fisheries/south-georgia-patagonian-toothfish-longline/@@assessments (accessed November 30, 2020).

Arton, A., Leiman, A., Petrokofsky, G., Toonen, H., and Longo, C. S. (2020) What do we know about the impacts of the Marine Stewardship Council seafood ecolabelling program? a systematic map. Environ. Evid. 9:6. doi: 10. 1186/s13750-020-0188-9

Baird, R. (2005). CCAMLR initiatives to counter flag state non-enforcement in Southern Ocean fisheries. Vic. Univ. Wellingt. Law Rev. 36:773. doi: 10.26686/ vuwlr.v36i4.5614

Barendse, J., Roel, A., Longo, C., Andriessen, L., Webster, L. M., Ogden, R., et al. (2019). DNA barcoding validates species labelling of certified seafood. Curr. Biol. 29, R198-R199. doi: 10.1016/j.cub.2019.02.014

Bellchambers, L. M., Gaughan, D. J., Wise, B. S., Jackson, G., and Fletcher, W. J. (2016). Adopting marine stewardship council certification of western australian fisheries at a jurisdictional level: The benefits and challenges. Fish. Res. 183, 609-616.

Booth, H., Pooley, S., Clements, T., Iqbal, M., Putra, H., Lestari, W. P., et al. (2020). Assessing the impact of regulations on the use and trade of wildlife: an operational framework, with a case study on manta rays. Glob. Ecol. Cons. 22:e00953. doi: 10.1016/j.gecco.2020.e00953

Brown, S., Agnew, D., and Martin, W. (2016). On the road to fisheries certification: the value of the objections procedure in achieving the MSC sustainability standard. Fish. Res. 182, 136-148. doi: 10.1016/j.fishres.2015.10.015

Bush, S. R., Asche, F., Sanchirico, J., Uchida, H., and Roheim, C. A. (2018) Evolution and future of the sustainable seafood market. Nat. Sustain. 1, 392398. doi: 10.1038/s41893-018-0115-Z

Butterworth, D. S. (2016). The South African experience with MSC certification: a perspective. Fish. Res. 182, 124-127. doi: 10.1016/j.fishres.2016. 02.021

Cabral, R. B., Mayorga, J., Clemence, M., Lynham, J., Koeshendrajana, S., Muawanah, U., et al. (2018). Rapid and lasting gains from solving illegal fishing. Nat. Ecol. Evol. 2, 650-658. doi: 10.1038/s41559-018-0499-1

Cannon, J., Sousa, P., Katara, I., Veiga, P., Spear, B., Beveridge, D., et al. (2018). Fishery improvement projects: performance over the past decade. Mar. Pol. 97, 179-187. doi: 10.1016/j.marpol.2018.06.007

Certification and Ratings Collaboration [CRC] (2018). Sustainable Seafood: A Global Benchmark. Horsham Township, PA: CRC.

Clarke, S. C., Harley, S. J., Hoyle, S. D., and Rice, J. S. (2013). Population trends in Pacific oceanic sharks and the utility of regulations on shark finning. Conserv. Biol. 27, 197-209. doi: 10.1111/j.1523-1739.2012.01943.x

Conservation Alliance for Seafood Solutions [CASS] (2019). Guidelines for Supporting Fishery Improvement Projects. Available online at: http://solutionsforseafood.org/wp-content/uploads/2019/09/FIP_report_ screen-final_revised_september.pdf (accessed 2 December, 2020).

Cusa, M., St John-Glew, K., Trueman, C., Mariani, S., Buckley, L., Neat, F., and Longo, C.S. (in review). A future for seafood provenance determination using DNA and stable isotope signatures. Rev Fish Biol Fish.

De Young, C., Charles, A., and Hjort, A. (2008). Human Dimensions of the Ecosystem Approach to Fisheries: an Overview of Context, Concepts, Tools and Methods. Rome: FAO. FAO Fisheries Technical Paper. No. 489.

Donlan, C. J., Wilcox, C., Luque, G. M., and Gelcich, S. (2020). Estimating illegal fishing from enforcement officers. Sci. Rep. 10:12478. doi: 10.1038/s41598-02069311-5
Dulvy, N. K., Simpfendorfer, C. A., Davidson, L. N. K., Fordham, S. V., Bräutigam, A., Sant, G., et al. (2017). Challenges and priorities in shark and ray conservation. Curr. Biol. 27, R565-R572. doi: 10.1016/j.cub.2017.04.038

Edwards, H. (2006). When predators become prey: the need for international shark conservation. Ocean Coastal L.J. 12, 305-354.

EJF (2019). Blood and Water: Human Rights Abuse in the Global Seafood Industry. Arlington, TX: EJF.

Fair Trade Usa [FTUSA] (2017). Capture Fishery Standard, Fair Trade USA version 1.1.0. Oakland, CA: Fair Trade USA.

Gascoigne, J., Collinson, K., and Phi, L. T. (2016). Marine Stewardship Council (MSC) Reduced re-assessment Public Certification Report Ben Tre Clams (Meretrix lyrata) On Behalf of the Client Ben Tre Department of Agriculture and Rural Development (DARD) Prepared by ME Certification Ltd. Available online at: https://fisheries.msc.org/en/fisheries/vietnam-ben-tre-clam-handgathered/@@assessments (accessed November 13, 2020).

Gavin, M. C., Solomon, J. N., and Blank, S. G. (2010). Measuring and monitoring illegal use of natural resources con. Biology 24, 89-100. doi: 10.1111/j.15231739.2009.01387.x

Glaus, K. B. J., Adrian-Kalchhauser, I., Piovano, S., Appleyard, S. A., Brunnschweiler, J. M., and Rico, C. (2018). Fishing for profit or food? socioeconomic drivers and fishers' attitudes towards sharks in Fiji. Mar. Policy 100, 249-257. doi: 10.1016/j.marpol.2018.11.037

Global Fishing Watch (2020). New Map Brings Improved Ocean Insights. Available online at: https://globalfishingwatch.org/about-us/ (accessed March 30, 2020).

González, A. F., Rivero, G. M., and Quílez, G. (2021). Marine Stewardship Council (MSC) Fisheries Assessments. Western Asturias Octopus Traps Fishery of Artisanal Cofradías, Public Comment Draft Report (PCDR), 15th June 2021. Available online at: https://fisheries.msc.org/en/fisheries/western-asturiasoctopus-traps-fishery-of-artisanal-cofradias/@@assessment-documentsets? documentset_name $=$ Public + comment+draft+report\&assessment_id $=$ FA02542\&phase_name $=$ Public + Comment+Draft+Report \&start_date=2020 - 1105\&title=Re-Assessment+v2.2 (accessed July 1, 2021).

Hilborn, R., Anderson, C. M., Kruse, G. H., Punt, A. E., Sissenwine, M., Oliver, C., et al. (2019). Pramod et al. methods to estimate IUU are not credible. Mar. Pol. 108:103632. doi: 10.1016/j.marpol.2019.103632

Indian Ocean Tuna Commission [IOTC] (2016). Resolution 16/02 on Harvest Control Rules for Skipjack Tuna in the IOTC Area of Competence. Victoria: IOTC.

iNewsGuyana (2015). Guyana Working Towards Marine Stewardship Certification. Available online at: https:/www.inewsguyana.com/guyana-working-towardsmarine-stewardship- certification/ (accessed 10 March, 2021).

IntraFish. (2020). GAA-backed Body Floats Fishing Vessels Safety Standard. Available online at: https://www.intrafish.com/fisheries/gaa-backed-bodyfloats-fishing-vessels-safety- standard/2-1-825379 (accessed December 02, 2020).

IPBES (2019). "Summary for policymakers of the global assessment report on biodiversity and ecosystem services of the Intergovernmental Science-Policy Platform on Biodiversity and Ecosystem Services," in IPBES Secretariat, eds S. Diaz, J. Settele, E. S. Brondízio, H. T. Ngo, M. Guèze, J. Agard, et al. (Bonn: IPBES).

ISEAL (2017). Governments and Private Sustainability Standards: An ISEAL Case Studies Series. Sycamore, ILL: ISEAL.

IUCN (2019). The IUCN Red List of Threatened Species. Gland: IUCN.

Jagers, S. C., Berlin, D., and Jentoft, S. (2012). Why comply? attitudes towards harvest regulations among Swedish fishers. Mar. Policy 36, 969-976. doi: 10. 1016/j.marpol.2012.02.004

Karnad, D., Sutaria, D., and Jabado, R. W. (2019). Local drivers of declining shark fisheries in India. Ambio 49, 626-627. doi: 10.1007/s13280-019-01203-z

Kittinger, J. N., Teh, L. C., Allison, E. H., Bennett, N. J., Crowder, L. B., Finkbeiner, E. M., et al. (2017). Committing to socially responsible seafood. Science 356, 912-913. doi: 10.1126/science.aam9969

Knight, C. J., Burnham, T. L. U., Mansfield, E. J., Crowder, L. B., and Micheli, F. (2020). COVID- 19 reveals vulnerability of small-scale fisheries to global market systems. Lancet Plan. Health 4:e219. doi: 10.1016/S2542-5196(20) 30128-5

Komives, K., Arton, A., Baker, E., Kennedy, E., Longo, C. S., Pfaff, A., et al. (2019). Conservation Impacts of Voluntary Sustainability Standards: How has Our Understanding Changed Since the 2012 Publication of 'Toward Sustainability: 
The Roles and Limitations of Certification'?. Washington, DC: Meridian Institute.

Lajus, D., Stogova, D., and Keskitalo, E. C. H. (2018). The implementation of Marine Stewardship Council (MSC) certification in Russia: achievements and considerations. Mar. Pol. 90, 105-114. doi: 10.1016/j.marpol.2018.01.001

Lewis, S., Alifano, A., Boyle, M., and Mangel, M. (2017). "Chapter 18 - human rights and the sustainability of fisheries," in Conservation for the Anthropocene Ocean, eds P. S. Levin and M. R. Poe (Cambridge, MA: Academic Press). doi: 10.1016/B978-0-12-805375-1.00018-0

Lewison, R. L., Crowder, L. B., Read, A. J., and Freeman, S. A. (2004). Understanding impacts of 788 fisheries bycatch on marine megafauna. Trends Ecol. Evol. 19, 598-604. doi: 10.1016/j.tree.2004.09.004

Macfadyen, G., Caillart, B., and Agnew, D. J. (2016). Review of Studies Estimating Levels of IUU Fishing and the Methodologies Utilized. Portmore: Poseidon Aquatic Resource Management Ltd.

Mackay, M., Hardesty, B. D., and Wilcox, C. (2020). The intersection between illegal fishing, crimes at sea, and social well-being. Front. Mar. Sci. 7:589000. doi: 10.3389/fmars.2020.589000

Marine Stewardship Council [MSC] (2016). Global Impacts Report 2016. London: MSC.

Marine Stewardship Council [MSC] (2018). MSC Fisheries Standard v2.01. London: MSC.

Marine Stewardship Council [MSC] (2019a). Making Waves: Small-scale Fisheries Achieving Sustainability with the MSC. London: MSC.

Marine Stewardship Council [MSC] (2019b). MSC Chain of Custody Standard: Default Version 5.0. London: MSC.

Marine Stewardship Council [MSC] (2020c). Ending Shark Finning. London: MSC. Available online at: https://www.msc.org/what-828 we-are-doing/endingshark-finning (accessed November 30, 2020).

Marine Stewardship Council [MSC] (2020b). MSC Annual Report 2019-2020. London: MSC. Available online at: https://www.msc.org/about-the-msc/ reports-and-brochures (accessed November 30, 2020).

Marine Stewardship Council [MSC]. (2020a). MSC Fisheries Certification Process and Guidance: Version 2.20. London: MSC.

Marine Stewardship Council [MSC] (2021). MSC Briefing 01. Small Pelagic Fisheries. London: MSC.

Martin, S. M., Cambridge, T. A., Grieve, C., Nimmo, F. M., and Agnew, D. J. (2012). An evaluation of environmental changes within fisheries involved in the marine stewardship council certification scheme. Rev. Fish. Sci. 20, 61-69. doi: 10.1080/10641262.2011.654287

MRAG Americas (2020). West Kamchatka Salmon Zarya-Kolpakovsky Sobolevo Final Report and Determination. London: MRAG.

Mustika, P. L. K., Ichsan, M., and Booth, H. (2020). The economic value of shark and ray tourism in Indonesia and its role in delivering conservation outcomes. Front. Mar. Sci. 7:261. doi: 10.3389/fmars.2020.00261

Palacios-Abrantes, J., Reygondeau, G., Wabnitz, C. C. C., and Cheung, W. W. L. (2020). The transboundary nature of the world's exploited marine species. Sci. Rep. 10:17668. doi: 10.1038/s41598-020-74644-2

Pomeroy, R., Parks, J., Courtney, K., and Mattich, N. (2016). Improving marine fisheries management in Southeast Asia: results of a regional fisheries stakeholder analysis. Mar. Policy 65, 20-19. doi: 10.1016/j.marpol.2015.12.002

Pramod, G., Pitcher, T. J., and Mantha, G. (2019). Estimates of illegal and unreported seafood imports to Japan. Mar. Pol. 108:103439.

Praxis Labs (2019). Tracking Progress: Assessing business Responses to Forced labour and Human Trafficking in the Thai Seafood Industry. San Francisco, CA: Praxis Labs.

Robinson, L., van Putten, I., Cavve, B., Longo, C., Watson, M., Bellchambers, L., et al. (2021). Understanding societal approval of the fishing industry and the influence of third-party sustainability certification. Fish Fish 1-14. doi: 10.1111/ faf. 12583

Secretariat of the Convention on Biological Diversity [SCBD] (2020). Global Biodiversity Outlook 5. Montreal, MTL: SCBD.

SFP (2012). Barents Sea Cod and Haddock Fishery Improvement Project. Available online at: https://www.sustainablefish.org/Media/Files/FIP-Archive-Reports/ Barents-Sea-Cod-and-Haddock-FIP-Archive (accessed January 16, 2021).

Shiffman, D. S., and Hammerschlag, N. (2016). Shark conservation and management policy: a review and primer for non-specialists. Anim. Conserv. 19, 401-412. doi: 10.1111/acv.12265
Shiffman, D. S., and Hueter, R. E. (2017). A United States shark fin ban would undermine sustainable shark fisheries. Mar. Policy 85, 138-140. doi: 10.1016/ j.marpol.2017.08.026

Simpfendorfer, C. A., and Dulvy, N. K. (2017). Bright spots of sustainable shark fishing. Curr. Biol. 27, R97-R98. doi: 10.1016/j.cub.2016.12.017

Song, A. M., Scholtens, J., Barclay, K., Bush, S. R., Fabinyi, M., Adhuri, D. S., et al. (2020). Collateral damage? Small-scale fisheries in the global fight against IUU fishing. Fish Fish. 21, 831-843. doi: 10.1111/faf.12462

Spiegel, J. (2001). Even jaws deserves to keep his fins: outlawing shark finning throughout global waters. B.C. Int'l Comp. L. Rev. 24, 409-438.

Steering Committee of the State of Knowledge Assessment of Standards and Certification [SCSKASC] (2012). Toward sustainability: The roles and limitations of certification. Washington, DC: Resolve, Inc.

Stratoudakis, Y., Azevedo, M., Farias, I., Macedo, C., Moura, T., Pólvora, M. J., et al. (2015a). Benchmarking for data-limited fishery systems to support collaborative focus on solutions. Fish. Res. 171, 122-129. doi: 10.1016/j.fishres.2014. 10.001

Stratoudakis, Y., McConney, P., Duncan, J., Ghofar, A., Gitonga, N., Mohamed, S. K., et al. (2015b). Fisheries certification in the developing world: locks and keys or square pegs in round holes? Fish. Res. 182, 39-49. doi: 10.1016/j.fishres. 2015.08.021

Sullivan-Sealey, K. (2011). Assessment of IUU (Illegal Unreported and Unregulated Fishing in the Bahamian Spiny lobster fishery Univ. Miami, FL: Department of Biology University of MiamiCoral Gables.

Tickler, D., Meeuwig, J. J., Bryant, K., David, F., Forrest, J. A. H., Gordon, E., et al. (2018). Modern slavery and the race to fish. Nat. Commun. 9:4643.

Tindall, C., Lees, S., Schley, D., Longo, C., and Oloruntuyi, O. (in prep). Mitigating forced labour risks on fishing vessels: understanding the state of play within Marine Stewardship Council (MSC) fisheries. Mar Pol.

Toonen, H. M., and Bush, S. R. (2020). The digital frontiers of fisheries governance: fish attraction devices, drones and satellites. J. Environ. Pol. Plann. 22, 125-137. doi: 10.1080/1523908X.2018.1461084

Travaille, K. L. (2020). The Utility of Fishery Improvement Projects (FIPs) for Governing Fishery Transitions Towards Sustainability. doctoral dissertation, Crawley WA: The University of Western Australia.

Travaille, K. L., Lindley, J., Kendrick, G. A., Crowder, L. B., and Clifton, J. (2019). The market for sustainable seafood drives transformative change in fishery social-ecological systems. Glob. Environ. Change 57:101919. doi: 10.1016/j. gloenvcha.2019.05.003

UN World Food and Agriculture Organization [FAO] (2020b). Regional Plan of Action to Prevent, Deter and Eliminate Illegal, Unreported and Unregulated (IUU) Fishing in WECAFC Member Countries (2019-2029). Rome: FAO.

UN World Food and Agriculture Organization [FAO] (2020c). Report on Work in the Fight Against Illegal, Unreported and Unregulated Fishing in Asia and the Pacific. FAO Regional Conference For Asia and the Pacific. Rome: FAO.

UN World Food and Agriculture Organization [FAO] (2001). International Plan of Action to Prevent, Deter, and Eliminate Illegal, Unreported and Unregulated Fishing (IPOA-IUU). Rome: FAO.

UN World Food and Agriculture Organization [FAO] (2016a). Agreement on Port State Measures to Prevent, Deter and Eliminate Illegal, Unreported and Unregulated Fishing (PSMA). Rome: FAO.

UN World Food and Agriculture Organization [FAO] (2016b). Seafood Traceability Systems: Gap Analysis of Inconsistencies in Standards and Norms, by Melania Borit and Petter Olsen. Rome: FAO. Fisheries and Aquaculture Circular No. 1123.

UN World Food and Agriculture Organization [FAO] (2020d). FAO yearbook. Fishery and Aquaculture Statistics 2018/ FAO annuaire. Statistiques des p^eches et de l'aquaculture 2018/ FAO anuario. Estadísticas de pesca y acuicultura 2018. Rome: FAO.

UN World Food and Agriculture Organization [FAO] (2020a). The State of World Fisheries and Aquaculture 2020. Rome: FAO.

van Putten, I., Longo, C. S., Arton, A., Watson, M., Anderson, C. M., Himes-Cornell, A., et al. (2020). Shifting focus: the impacts of sustainable seafood certification. PLoS One 15:e0233237. doi: 10.1371/journal.pone. 0233237

Vietnam News Agency [VNA] (2018). Mekong Clam Farmers Develop Sustainable Value Chains. Hanoi: Viet Nam News. 
Vietnam News Agency [VNA] (2020). Ben Tre Steps up Installation of Fishing Vessel Monitoring Devices. Hanoi: Viet Nam News.

WWF (2018). Living Planet Report 2018: Aiming Higher. Glan: WWF.

Xuan, D. L., and Seip-Markensteijn, C. (2019). Marine Stewardship Council (MSC) 3rd Surveillance Audit Report Ben Tre hand-gathered clam fishery On behalf of Ben Tre Department of Agriculture and Rural Development (DARD). London: MSCongoDownloads.

Conflict of Interest: CL, LB, LK, SL, SYL, OO, DS, and RC are currently employed by the Marine Stewardship Council (MSC).

The remaining authors declare that the research was conducted in the absence of any commercial or financial relationships that could be construed as a potential conflict of interest.
Publisher's Note: All claims expressed in this article are solely those of the authors and do not necessarily represent those of their affiliated organizations, or those of the publisher, the editors and the reviewers. Any product that may be evaluated in this article, or claim that may be made by its manufacturer, is not guaranteed or endorsed by the publisher.

Copyright (๑) 2021 Longo, Buckley, Good, Gorham, Koerner, Lees, Liow, Oloruntuyi Schley, Rice and Currey. This is an open-access article distributed under the terms of the Creative Commons Attribution License (CC BY). The use, distribution or reproduction in other forums is permitted, provided the original author(s) and the copyright owner(s) are credited and that the original publication in this journal is cited, in accordance with accepted academic practice. No use, distribution or reproduction is permitted which does not comply with these terms. 